Ruba J Mohammed BDS, MSc (Asst. Lec.)

\section{Reliability of Soft Tissue Analysis in Conventional and Digital Cephalographs}

\author{
Dept of Pedod, Orthod and Prev Dentistry \\ College of Dentistry, University of Mosul
}

\begin{abstract}
الحلاصة
الأهداف : تمدف هذه الدراسة إلى مقارنة مصداقية قياسات التحليلات الخاصة بقياس الرأس للأنسجة الرخوية باستعمال التحليل الرقمي المباشر للصور الشعاعية

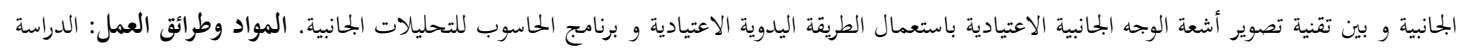

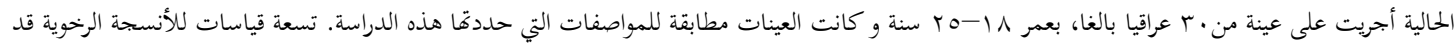

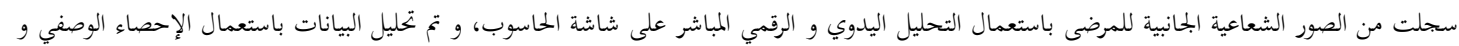

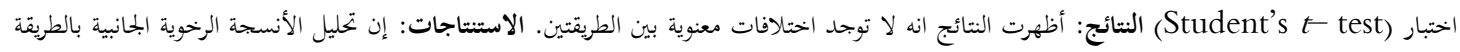

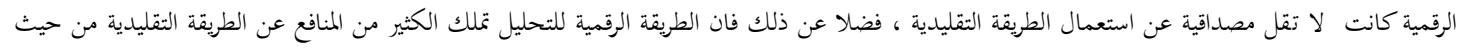

الإقلال من كمية الإشعاع و أن الصورة الإشعاعية يمكن تحسينها بطريقة مختلفة.
\end{abstract}

\title{
ABSTRACT
}

Aims: This study compared the reliability of measurements of soft tissue cephalometric analysis between the direct digital and conventional cephalometric images using computerized cephalometric program and hand tracing. Materials and Methods: The adult sample consisted of (30) Iraqi subjects (females and males) with age ranged 18 - 25 years old, the samples satisfied the criteria of this study. Nine soft tissue measurements were recorded from lateral cephalometric radiographs using either hand tracing or digitally directly on the monitor. The data were analyzed using descriptive statistic and student's $t$-test. Results: No significant differences were found between the conventional or hand tracing and digital cephalometric analysis. Conclusions: The analysis of soft tissue profile using digital cephalometric analysis is reliable as using the conventional method. Yet, the digital method had more benefit than the conventional method, such as reduction of the radiation dose and the image enhancement.

Key words: Cephalometric, Soft tissue analysis, Digital radiography, Conventional radiography.

Mohammed RJ. Reliability of Soft Tissue Analysis in Conventional and Digital Cephalographs. $A l-$ Rafidain Dent J. 2013; 13(1): 108-115.

Received: 19/9/2011 Sent to Referees: 22/9/2011

Accepted for Publication: 16/11/2011

\section{INTRODUCTION}

From ancient societies and cultures to our modern society, a great emphasis has been placed on the facial esthetics and physical attractiveness. The concept of esthetics is subjective, so, it is very hard to determine objective criteria of defining the concept of beauty. The aim of orthodontic treatment is to achieve a proper, functional occlusion together with a well balanced and esthetic facial profile; therefore many studies on the ideal relationship of skeletal and soft tissue have been carried out. ${ }^{(1-7)}$

Analysis of dental and skeletal patterns alone might be inadequate or misleading, because of marked variations in soft tissues covering the dento-skeletal framework. As treatment mechanics become more effective, there has been increased emphasis on the soft tissues in both diagnostic and treatment results. Cephalometric norms of various ethnic and racial groups have been established in many studies. Most investigators have concluded that there are significant differences between ethnic and racial groups, and many cephalometric standards have been developed for various ethnic groups. (8-13)

Investigators have developed numerous analyses to interpret the diagnostic information provided by the lateral cephalogram. ${ }^{(14)}$ 
Most investigations on the reliability of soft tissue cephalometric measurements using conventional and digital cephalometric analysis have dealt mainly with the skeletal reference points. ${ }^{(15-17)}$ Only a few authors have studied problems and benefits regarding the reproducibility of soft tissue measurements. ${ }^{(18-19)}$ Each radiographic exposure is a potential risk for the patient. The development of digital radiograph led to the further reduction in radiation without the loss of diagnostic quality in addition to other benefits like the image processing, the storage improvement and information access or transfer. ${ }^{(20)}$

The aim of this study is to find the most appropriate method of assessing soft tissue profile to be used both in clinical and research works.

\section{MATERIALS AND METHODS}

The samples of this study consisted of 30 adult males and females with age ranged between $18-25$ years who were selected from the students of College of Dentistry, University of Mosul and from the patients attending the Collage. The samples satisfied the criteria of balanced facial profile, class I molar relationship, competent lips and normal overbite overjet relationship and they have not received any previous orthodontic treatment. Two lateral cephalometric radiographs (conventional and digital) have been taken for each subject. The conventional radiographs were taken with cephalometric $\mathrm{x}-$ ray machine type Starto - M505 - Italy; operated at $78 \mathrm{kVp}, 12 \mathrm{~mA}$ and $0.8 \mathrm{sec}$. exposure time. Whereas, the digital radiographs were taken with Planmeca Dimaxis $\mathrm{x}$ - ray Pro-Finland; with $78 \mathrm{kVp}, 12 \mathrm{~mA}$ and 23 sec. scanning time according to manufacturer's instructions.

In each method, the subject's head was positioned in a cephalostat and oriented parallel to the Frankfort horizontal plane. The lips were in closed position and the teeth were in maximum intercuspation. The conventional lateral cephalographs were traced using acetate paper, the skeletal landmarks were determined as de- scribed by Thurow. ${ }^{(21)}$

The soft tissue landmarks were determined according to the definition of Chaconas and Batroff. ${ }^{(22)}$

The angular measurements included the following; the angle of soft tissue facial convexity excluding the nose $\left(\mathrm{n}^{\prime}-\mathrm{sn}-\right.$ $\left.\operatorname{pog}^{\prime}\right),{ }^{(23)}$ angle of total facial convexity $\left(n^{\prime}-\right.$ pr-pog') ${ }^{(23)}$ soft tissue facial plane angle ( $n^{\prime}-$ pog' $^{\prime}$ to Frankfort horizontal plane), ${ }^{(24)}$ nasolabial angle (the angle formed between the tangent, to columela of nose and $\mathrm{Sn}-\mathrm{Ls}),{ }^{(25)}$ mentolabial angle (angle formed between $\mathrm{Li}-\mathrm{B}^{\prime}$ and the tangent to the chin), ${ }^{(26)} \mathrm{Z}$ angle (which is formed between the $\mathrm{FH}$ plane and the line drawn from pog' $^{\prime}$ to the most protruding lip).

All sagittal and vertical linear dimensions were measured perpendicular and parallel to Frankfort horizontal plane respectively. The linear variables determined were measured by Zylinski et al., ${ }^{(26)}$ and included: upper lip length (sn-sto), lower lip length (sto-me') and nasal depth (pr$\left.n^{\prime}\right)$.

In the digital technique, the digital radiographs were traced directly on the monitor using Planmeca software program (Dimax classic imaging software, Finland). The identification of landmarks was performed with a mouse controlled cross hair cursor, the monitor (Bestview, Korea) with high definition $1024 \times 768$ pixel, the software program was calibrated prior to each individual tracing, and then the same soft tissue angular and linear parameters, calculated and displayed on the monitor according to manufacturer's instructions as shown in Figures (1) and (2) also the image manipulations (image magnification, reverse gray scale, contrast alteration and pseudo-coloring of the image) were used to enhance the image quality, in turn this facilitated the landmark identifications of the soft tissues analysis.

The data were analyzed using descriptive statistics including mean, standard deviation. Student's $t-$ test was used to examine the difference between the two methods at $p \leq 0.05$. 


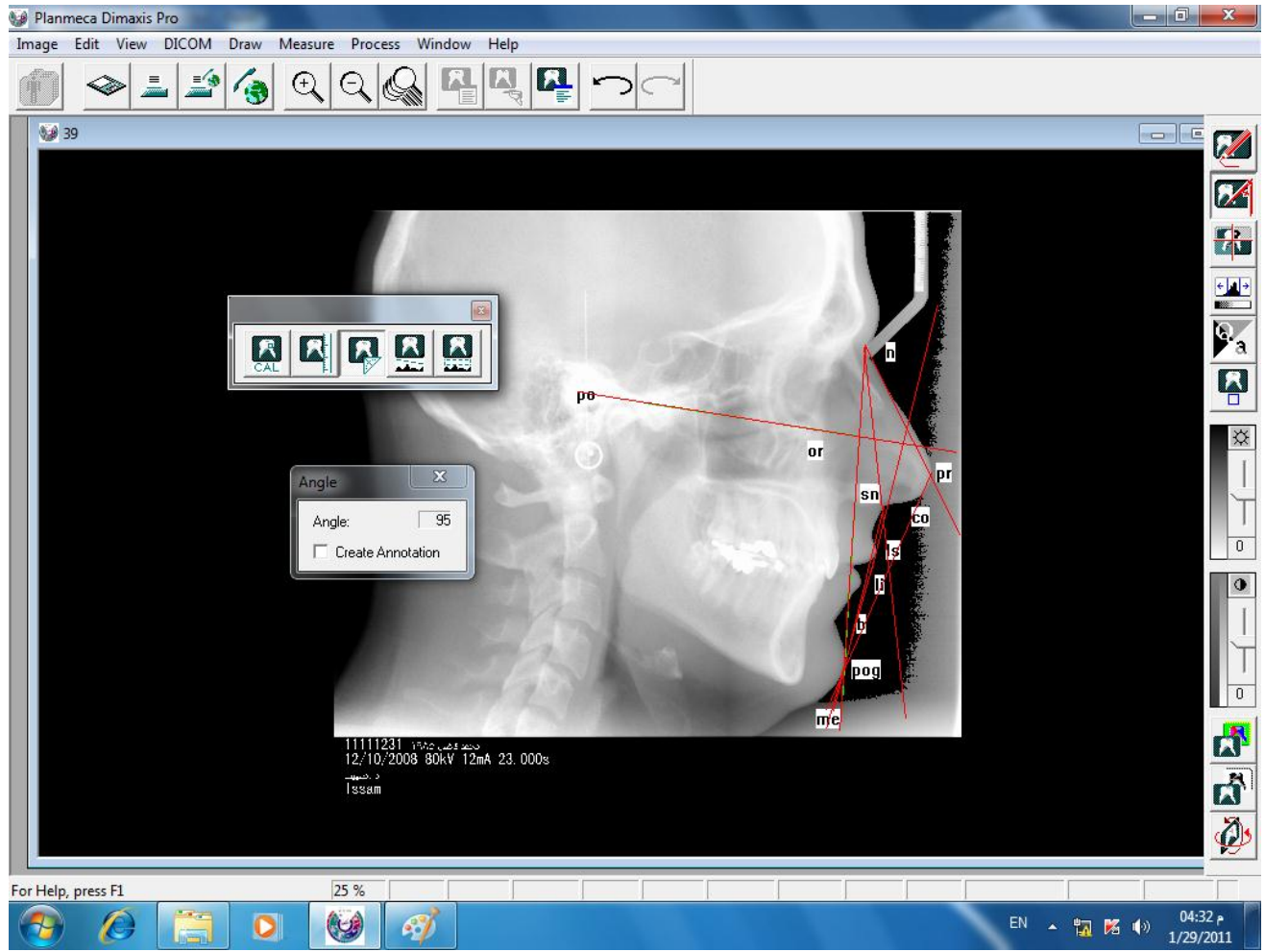

Figure (1): Angular measurements of soft tissue analysis within digital image.

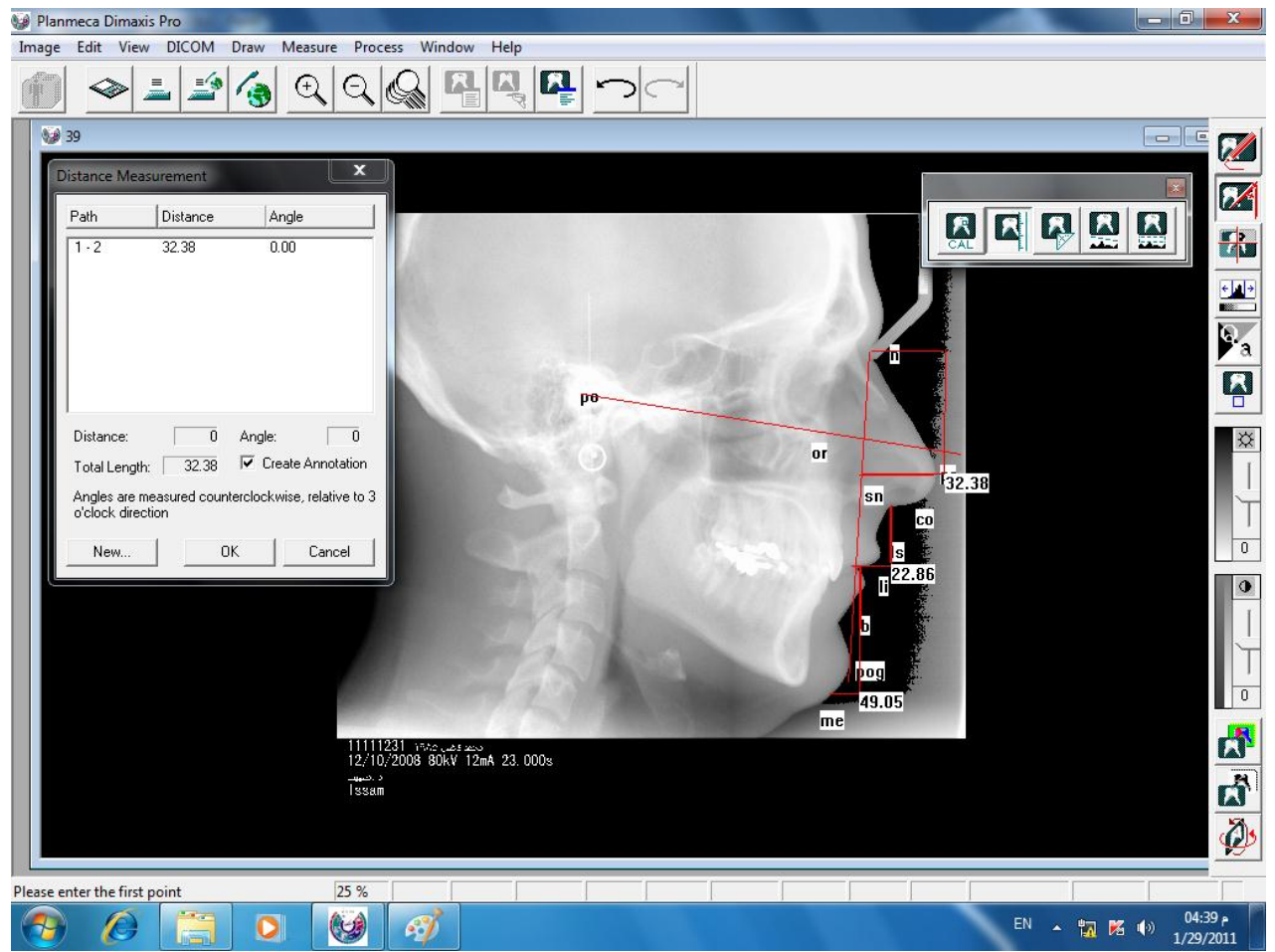

Figure (2): Linear measurements of soft tissue analysis within digital image. 
The descriptive statistics along with the results of Student's $t$ - test for the soft tissue parameters using the two methods (conventional and digital cephalographs) are presented in Table (1). No significant difference was noticed between the two methods regarding angular soft tissue measurements as shown in Table (1) and Figure (3).

Table (1): Angular and linear measurements of soft tissue analysis in conventional and digital methods.

\begin{tabular}{|c|c|c|c|c|c|c|c|c|c|}
\hline Variables & & Group & No. & Mean & SD & SE & $t$-value & df & $p$-value \\
\hline ń-sn--pog' & \multirow{12}{*}{$\begin{array}{l}\vec{\Xi} \\
\vec{E} \\
\vec{E}\end{array}$} & Conventional & 30 & 163.53 & 4.468 & 0.815 & \multirow{2}{*}{0.034} & \multirow{2}{*}{58} & \multirow{2}{*}{0.973} \\
\hline angle & & Digital & 30 & 163.50 & 2.956 & 0.539 & & & \\
\hline ń-pr-pog' & & Conventional & 30 & 127.70 & 4.247 & 0.775 & \multirow{2}{*}{-0.404} & \multirow{2}{*}{58} & \multirow{2}{*}{0.688} \\
\hline angle & & Digital & 30 & 128.13 & 4.064 & 0.741 & & & \\
\hline ń-pog' to & & Conventional & 30 & 90.01 & 6.551 & 1.196 & \multirow{2}{*}{-0.314} & \multirow{2}{*}{58} & \multirow{2}{*}{0.755} \\
\hline FH angle & & Digital & 30 & 90.42 & 2.893 & 0.528 & & & \\
\hline 7 angle & & Conventional & 30 & 74.23 & 7.942 & 1.450 & \multirow{2}{*}{-1.316} & \multirow{2}{*}{58} & \multirow{2}{*}{0.193} \\
\hline$Z$ - angle & & Digital & 30 & 76.39 & 4.214 & 0.769 & & & \\
\hline Nasolabial & & Conventional & 30 & 104.13 & 10.966 & 2.002 & \multirow{2}{*}{-0.281} & \multirow{2}{*}{58} & \multirow{2}{*}{0.780} \\
\hline angle & & Digital & 30 & 104.80 & 7.336 & 1.339 & & & \\
\hline Mentolabial & & Conventional & 30 & 135.70 & 8.636 & 1.576 & \multirow{2}{*}{0.238} & \multirow{2}{*}{58} & \multirow{2}{*}{0.813} \\
\hline angle & & Digital & 30 & 135.32 & 1.094 & 0.199 & & & \\
\hline Upper lip & \multirow{6}{*}{ 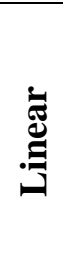 } & Conventional & 30 & 21.40 & 2.073 & 0.378 & \multirow{2}{*}{-0.345} & \multirow{2}{*}{58} & \multirow{2}{*}{0.731} \\
\hline length & & Digital & 30 & 21.69 & 4.164 & 0.760 & & & \\
\hline Lower lip & & Conventional & 30 & 49.10 & 1.872 & 0.341 & \multirow{2}{*}{-0.063} & \multirow{2}{*}{58} & \multirow{2}{*}{0.950} \\
\hline length & & Digital & 30 & 49.16 & 5.706 & 1.041 & & & \\
\hline acal denth & & Conventional & 30 & 28.53 & 3.342 & 0.610 & \multirow{2}{*}{0.189} & \multirow{2}{*}{58} & \multirow{2}{*}{0.851} \\
\hline Nasal depth & & Digital & 30 & 28.36 & 3.405 & 0.621 & & & \\
\hline
\end{tabular}

Angular variable are measured in degree, linear variables are measured in mm. No: Number; SD: Standard deviation; SE; Standard error of mean; df: Degree of freedom.

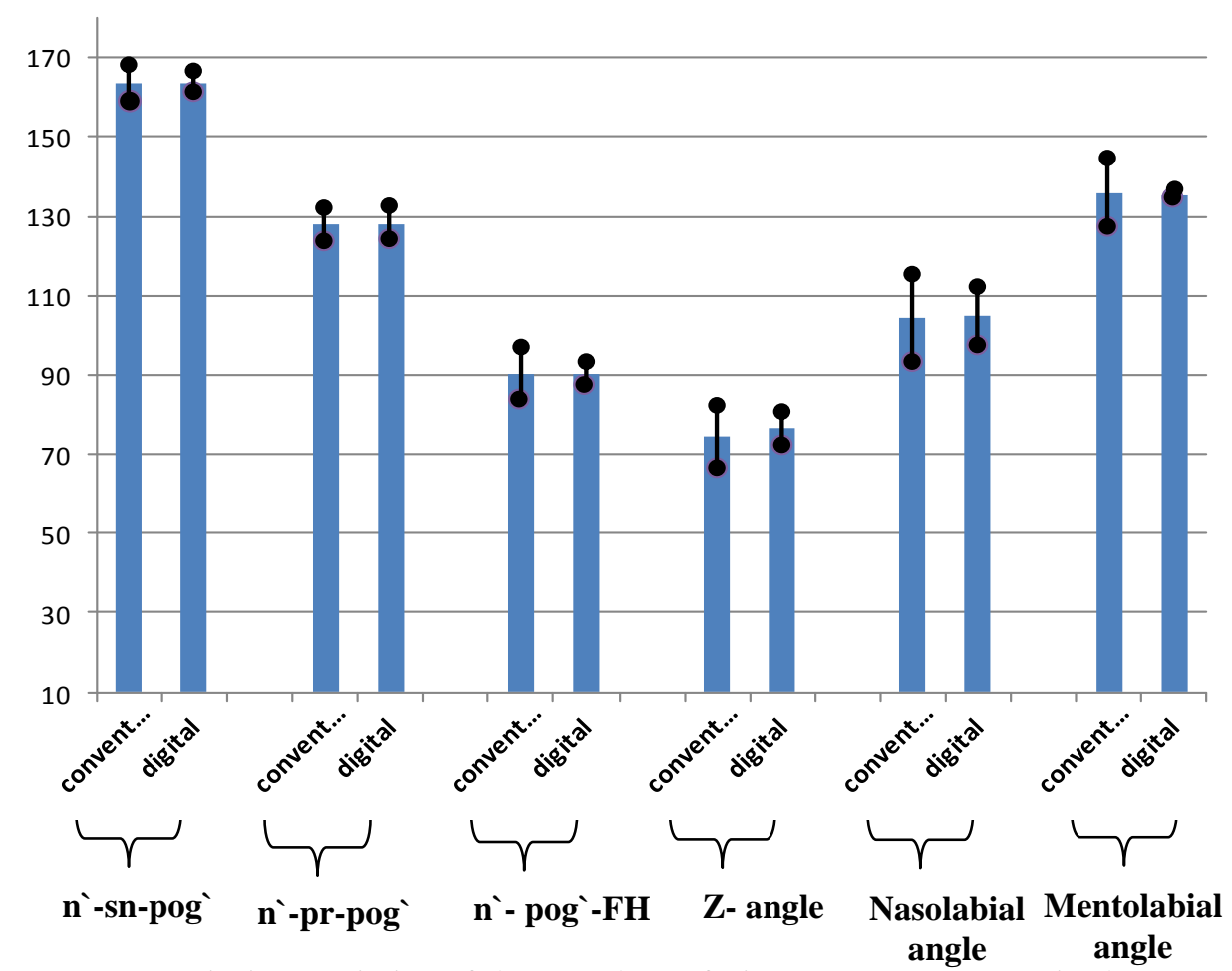

Figure (3): Descriptive statistics of the angular soft tissue measurements in the conventional and digital cephalographs. 
The linear soft tissue measurements also showed no significant statistical difference between the conventional and digi- tal cephalographs as shown in Table (1) and Figure (4).

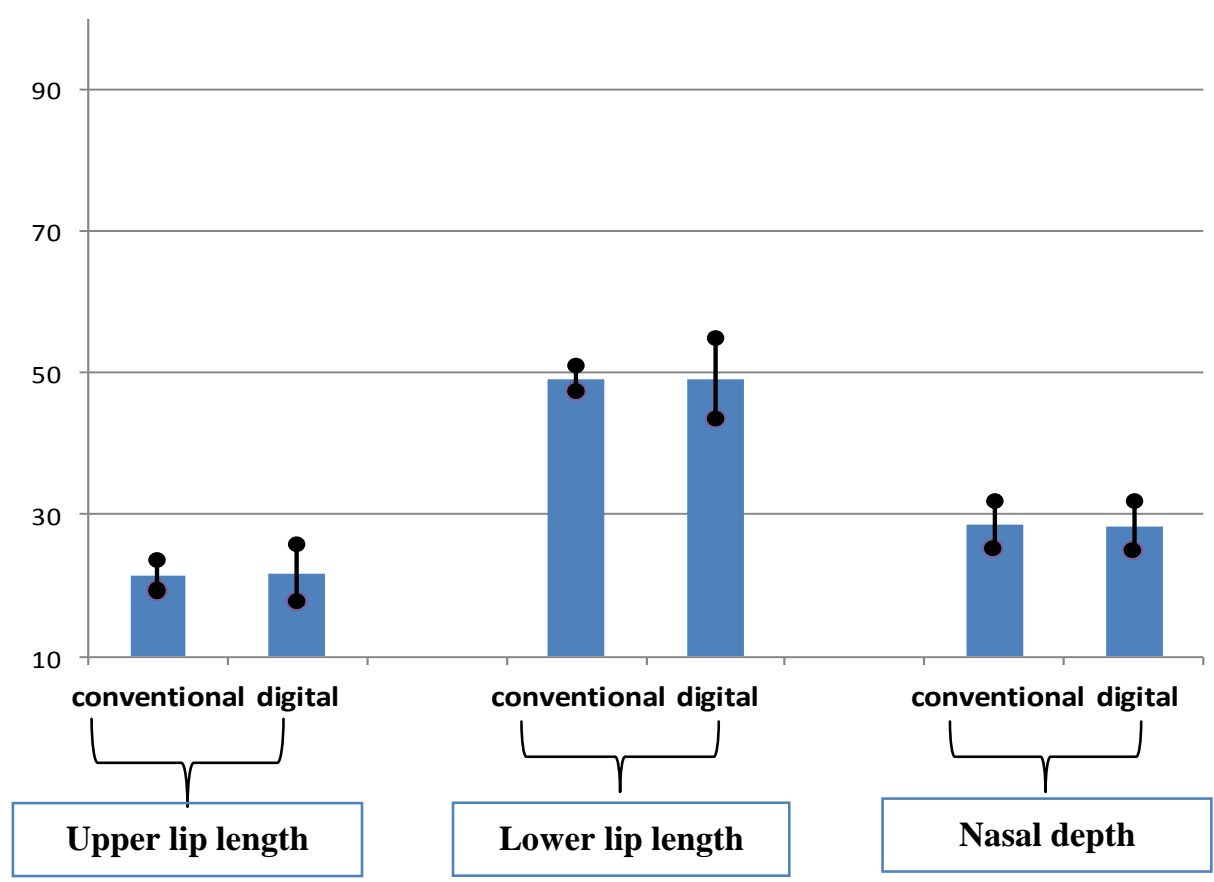

Figure (4): Descriptive statistics of the linear soft tissue measurements in the conventional and digital cephalographs.

\section{DISCUSSION}

In this study, the mean values of the angular and linear soft tissue measurements that have been done by the conventional tracing method were near to those angular and linear soft tissue measurements that have been done in the study of $\mathrm{Al}-\mathrm{Zubaidi}^{(27)}$ for the adults, when they are compared as shown in Table (2); although the nasolabial angle showed slight difference, but it is statistically acceptable, then according to these results, the mean values of all the angular and linear soft tissue measurements that have been done by digital method were compared and evaluated with those of conventional one and there were no significant differences between these results and this agreed with the findings of Kublashili et al., ${ }^{(19)}$ who reported no significant difference in the reliability of the measurements in regards to soft tissue cephalometric landmarks between digital and conventional images using different models of analysis.

In this study, the digital cephalometric analysis of the soft tissues was as reliable as the conventional method and this agreed with the study of Hwang et al., ${ }^{(25)}$ who sought to quantify objectively their clinical impressions of the soft tissue profile was not a simple matter, because the profile, as observed in the lateral head film, consisted of many curved lines.

The curved lines usually were converted to straight lines to quantify the soft tissue contours, and then these straight lines are compared to so called "normal values" and thus this agreed with results of this study which indicated that in digital analysis directly on the monitor, the construction of these straight lines is more reproducible over the time that required to do this analysis. ${ }^{(25)}$ 
Table (2): Comparison of the angular and linear measurements of the soft issue analysis in the present study and Al-Zubaidi study-2009.

\begin{tabular}{|c|c|c|c|c|c|c|}
\hline Variables & & Group & $\begin{array}{c}\text { Means } \\
\text { (present study) }\end{array}$ & $\begin{array}{l}\text { Means (Al-Zul } \\
\text { conventic }\end{array}$ & $\begin{array}{l}\text { aidi- } \\
\text { al n }\end{array}$ & $\begin{array}{l}\text { ldy 2009- } \\
\text { lod) }\end{array}$ \\
\hline & & Conventional & 163.53 & Conventional & $\mathrm{M}$ & 166.26 \\
\hline n-sn-pog & & Digital & 163.50 & Conventional & $\mathrm{F}$ & 162.60 \\
\hline & & Conventional & 127.70 & & $\mathrm{M}$ & 131.30 \\
\hline n -pr-pog & & Digital & 128.13 & Conventional & $\mathrm{F}$ & 128.36 \\
\hline ń - pog' $^{\prime}$ to & & Conventional & 90.01 & & M & 91.30 \\
\hline FH angle & $\bar{\pi}$ & Digital & 90.42 & Conventional & $\mathrm{F}$ & 90.90 \\
\hline & 50 & Conventional & 74.23 & & $\mathrm{M}$ & 78.90 \\
\hline Z-angle & & Digital & 76.39 & Conventional & $\mathrm{F}$ & 76.43 \\
\hline Naso-Labial & & Conventional & 104.13 & & $\mathrm{M}$ & 99.40 \\
\hline angle & & Digital & 104.80 & Conventional & $\mathrm{F}$ & 109.30 \\
\hline Mento- & & Conventional & 135.70 & & $\bar{M}$ & 133.40 \\
\hline Labial angle & & Digital & 135.32 & Conventional & $\mathrm{F}$ & 139.20 \\
\hline Upper lip & & Conventional & 27.40 & & $\mathrm{M}$ & 21.23 \\
\hline length & & Digital & 21.69 & Conventional & $\mathrm{F}$ & 20.86 \\
\hline Lower lip & $\Xi$ & Conventional & 49.10 & & $\mathrm{M}$ & 53.20 \\
\hline length & בנב & Digital & 49.16 & Conventional & $\mathrm{F}$ & 48.63 \\
\hline Nasal denth & & Conventional & 28.53 & Conventional & $\mathrm{M}$ & 28.73 \\
\hline Nasar depm & & Digital & 28.36 & Comventional & $\mathrm{F}$ & 27.40 \\
\hline
\end{tabular}

M; male. F; female.

Moreover in this study, the image manipulation was used to clarify and make the digital radiographic images more better for viewing with best resolution in order to facilitate the land marks identification and thus made digital analysis more reliable as the conventional one and this agreed with results of Quintero et al., and Ferreira et $a l .{ }^{(28,29)}$ who showed that the use of digital imaging allowed the operator to manipulate data on a computer, facilitating the complex analysis, and organization that were required, also they found the sto-me' and sn-sto measurements could be more precise by using all variables resources for altering the computerized radiographic images.

Also, the results of this study come into agreement with Celik et al. ${ }^{(30)}$ who found no significant differences in the soft tissue measurements between the conventional and digital images, they revealed that during conventional hand tracing, different reference planes may be constructed to identify the inner most points of a curve, therefore, measurements of the nasolabial angle which was constructed on a curve may show great variation. So that, computerized cephalometric measurements using direct digital imaging was inherently preferable for its user - directly and time saving characteristics.

In addition, the results of this study agreed with Galderazzi et al., ${ }^{(31)}$ who reported that the digital imaging technique provided better visualization of soft tissue structures, also the image manipulation that available within the image software programs would facilitate and make the landmarks identification, either the hard and soft tissue more accurately and easily. Therefore, when all digital technologies were applied together correctly in an interdisciplinary approach they will fertilize each other resulting in more precise diagnosis improved treatment results and better communications and this agreed with the study of Ogodescu et al., ${ }^{(32)}$.

\section{CONCLUSIONS}

There was no significant difference in the reliability of measurements in regard to soft tissue cephalometric analysis between the conventional and digital cephalometric images, although the digital method showed more accuracy in their measurements. It has been suggested in many studies that in the future, conven- 
tional radiographs will become obsolete and will be replaced by digital images.

\section{REFERENCES}

1. Ricketts RM. Planing treatment on the basis of the facial pattern and estimate of its growth. Angle Orthod. 1957; 27: 14 37.

2. Steiner CC. The use of the cephalometric as an aid to planning and assessing orthodontic treatment. Am J Orthod. 1960; 46: 791-795.

3. Merrifield LL. The profile line as an aid in critically evaluating facial esthetics. Am J Orthod. 1966; 52: 804 - 822.

4. Burstone CJ. Lip posture and its significance in treatment planning. Am J Orthod. 1967; 53: $262-284$.

5. Suchner NI. A photographic study of the soft tissue profile of the Negro population. Am J Orthod. 1977; 72: 373 - 385.

6. Holdaway RA. A soft tissue cephalometric analysis and its use in orthodontic treatment planning. Part I. Am J Orthod. 1983; 84: $1-28$.

7. Türkkarhraman $H$, Gökalp $H$. Facial profile preferences among various layers of Turkish population. Angle Orthod. 2004; 74: 640 - 647.

8. Talal Al-Gunaid, Kazuhiro Yamada, Masaki Yamaki. Soft -tissue cephalometric norms in Yemeni men. Am J Orthod Dentofacial Orthop. 2007; 132(5); $576-578$.

9. Tarja Virkkula, Tuomo Kantomaa, Johanna Julku, Pertti Pirttiniemi. Long-term soft-tissue response to orthodontic treatment with early cervical headgear- a randomized stydy. Am J Orthod Dentofacial Orthop. Available online 1 May 2009.

10.Hwang HS, Kim WS, McNamara JA. Ethnic differences in the soft tissue profile of Korean and European - American adults with normal occlusions and well balanced faces. Angle Orthod. 2002; 72: $72-80$.

11.Nanda R, Nanda RS. Cephalometric study of the dentofacial complex of North Indians. Angle Orthod. 1969; 39: 22 - 28.

12. Arnett GW, Bregman RT. Facial keys to orthodontic diagnosis and treatment planning . Part I. Am J Orthod Dentofacial Orthop. 1993; 103: 299 - 312.

13. Kalha AS, Latif A, Govardhan SN. Soft tissue cephalometric norms in a South In- dian ethnic population. Am J Orthod Dentofacial Orthop. 2008; 133(6): 876 - 881.

14.El-Habidy M, El-din MB, El-Bassioni L, Attah W. Cephalometric analysis for evaluating the profile nasal morphology in Eqyption adults. Eygpt $J$ Plast Reconst Surg. 2007; 31(2): $243-249$.

15.Geelen W, Wenzel A, Golfredsen E, Kruger M, Hansson L. Reproducibility of cephalometric landmarks on conventional film, hard copy and monitor - displayed images obtained by the storage phosphor technique. Eur J Orthod. 1998; 20: 331 340.

16. Mari Eli Leonelli de Moraes, Lars G Hollender, Curtis S. K. Chen, Luiz C. Moraes, Ivan Balducci. Evaluating craniofacial asymmetry with digital ceohalometric images and cone beam computed tomography. Am J Orthod Dentofac Orthop. 2011; 139(6): e523 - e531.

17.Davis DN, Mackay F. Reliability of cephalometric analysis using manual and interactive computer methods. $\mathrm{Br} \mathrm{J} \mathrm{Or}$ thod. 1991; 18: 105 - 109.

18.Hagemann K, Vollmer D, Niegel $T$, Ehmer U, Renter I. Perspective study on the reproducibility cephalometric landmarks on conventional and digital lateral head films. J Orthofac Orthop. 2000; 67: $91-99$.

19. Kublashvili T, Kula K, Craven R, Vadachkoria Z. Reliability of soft tissue cephalometric parameter using conventional and digital cephalometric radiogram. Ann Biomed Res Educ. 2002; 2(4): $316-322$.

20.Forsyth DB, Morth FDC, Shaw WC, Richmond S, Roberts CT. Digital imaging of cephalometric radiographs. Part 2: image quality. Angle Orthod. 1996; 66: 43 50.

21.Thurow RC. Atlas of orthodontic principles. St. Louis. CV Mosby. 1970. Pp. $30-$ 89.

22.Chaconas SJ, Bartroff JD. Prediction of normal soft tissue changes. Angle Orthod. 1975; 45: $12-25$.

23. Subtelny JD. A longitudinal study of soft tissue facial structures and their profile characteristics defined in relation to underlying skeletal structure. Am J Orthod. 1959; 45: 481 - 507.

24.Neger M. A quantitative method for the evaluation of soft tissue profile. Am J Or- 
thod. 1959; 45: 738 - 751.

25.Hwang HS, Kin WS, McNamara JA. A comparative study of two methods of quantifying the soft tissue profile. Angle Orthod. 2000; 70(3): 200 - 207.

26.Zylinski CG, Nanda RS, Kapila S. Analysis of soft tissue facial profile in white males. Am J Orthod Dentofacial Orthop. 1992; 101: $514-518$.

27.Al-Zubaidi SH. The skeletal and soft tissue facial profile in adolescent and adult. Al-Rafidain Dent J. 2009; 9(1): 149 -155 .

28. Quintero JC, Trosien A, Hatcher D, Kapila S. Craniofacial imaging orthodontics: historical perspective. Curr Status Fut Develp. 1999; 69(6): 491 - 506.

29.Ferreira JTL, Telles CS. Evaluation of reliability of computerized profile cephalometric analysis. Braz Dent J. 2002; 13(3):201-204.

30.Celik E, Polot-Ozsoy O, Memikoglu TT. Comparison of cephalometric measurements with digital versus conventional cephalometric analysis. Eur $J$ Orthod. 2009; 31: 241 - 246.

31.Galderazzi A, Palla L, Battolla L, Ceramlla D, Barbieri L. La radiologia digitale confosforia memoria. Nello studio Cephalometrico nell. Orthod Radiol Med (Torino). 1992: $216-220$.

32. Alexandru S, Ogodescu CS, Emilia A, Ogodescu MN, Brata E. Digital tools in the interdisciplinary orthodontic treatment of adult patients. Int J Bio Biomed Eng. 2010; 4(4): 95 - 105. 